DOI: https://doi.org/10.24127/ajpm.v9i3.2779

\title{
THE MATHEMATICS LEARNING MODEL'S FOR EARLY GRADE STUDENTS: CONTEXTUAL OR PROBLEM-BASED LEARNING
}

\author{
Moh. Farizqo Irvan ${ }^{1 *}$, Mohammad Adam Jerusalem², Habibullah ${ }^{3}$ \\ ${ }^{1,2,3}$ Universitas Negeri Yogyakarta, Yogyakarta, Indonesia \\ ${ }^{*}$ Corresponding author. Jalan Colombo No. 1 Depok, Sleman, 55281, Yogyakarta, Indonesia \\ E-mail: $\quad$ mohfarizqo.2018@student.uny.ac.id ${ }^{1 *)}$ \\ adam_jerusalem@uny.ac.id ${ }^{2)}$ \\ $\underline{\text { habibullah_nz@yahoo.co.id }}^{3)}$
}

Received 24 April 2020; Received in revised form 07 September 2020; Accepted 14 September 2020

\begin{abstract}
This research aimed to know the appropriate learning model was applied in early grade mathematics learning by showed the differences in mathematics learning outcomes of students who use contextual teaching-learning and problem-based learning. This research method was quasi-experiment with a posttest only control group design. The population of this research were 3rd grade students of SD Negeri Wonosari, Semarang City. The sampling technique was used to cluster random sampling with two experimental classes. The first experimental class used contextual teaching-learning and the second experimental class used problem-based learning. The data were analyzed using a one-way ANOVA test. The results showed that there were differences between student mathematics learning outcomes in three classes. Student learning outcomes that applied contextual teaching and learning were better than mathematics learning outcomes of students who applied problem-based learning or conventional learning because contextual teaching and learning more emphasis on meaningful learning from real life that made it easier for students to understand. The teacher should be able to choose the appropriate model to be applied in mathematics learning following the grade level so that mathematics learning in the early grade could run optimally. So, this model was suitable to apply in early grade mathematics learning.
\end{abstract}

Keywords: Contextual teaching and learning; early grade; learning model; mathematics learning; problem-based learning.

This is an open access article under the Creative Commons Attribution 4.0 International License

\section{INTRODUCTION}

An increasingly complex life requires teachers to equip students with the sciences needed in life. The provision of knowledge can be done formally and informally. The formal provision of knowledge can be done through learning in the classroom. One of them is mathematics learning.

Mathematics learning in elementary schools has an important role because it is the basis of learning mathematics at the next level which is increasingly complex. Riyanti, Sutama,
\& Maryadi (2017) stated that learning mathematics in elementary schools is useful for the benefit of living in their environment, to develop their mindset, and to learn other sciences. The benefits of learning mathematics are obtained if students succeed in participating in learning. The success of learning in the classroom is influenced by various factors, one of which is the model applied by the teacher in learning. The application of the learning model that is not appropriate results in the learning process that is not optimal, so that it 
DOI: https://doi.org/10.24127/ajpm.v9i3.2779

affects student learning outcomes. Therefore, teachers should have the initiative in determining and implementing a learning model that is in accordance with the conditions of students, so that learning objectives can be maximally achieved.

The determination of the models applied by the teacher in learning must be adapted to the conditions and needs of students. The application of a learning model that is in accordance with the conditions and needs of students will have a positive impact on the learning process and student learning outcomes (Kahar, Anwar, \& Murpri, 2020). There are several reasons for determining the model applied in mathematics learning. Mu'min, Kamelia, \& Halmuniati (2017) state that the determination of the learning model is based on the conditions and needs of students' learning styles. In addition, learning material is also one of the reasons for determining the appropriate learning model in learning (Astriyani, 2016). However, based on existing studies, there has been no research that tries to determine a learning model based on the level of education of students, especially in elementary schools, which divides the age of the study group into early and high grades.

Based on observations and interviews with third-grade teachers at SDN Wonosari 01, SDN Wonosari 02, and SDN Wonosari 03, there are several problems in learning mathematics, such as students lacking focus, passivity, and lack of confidence during learning. So that it has an impact on student learning outcomes are low. The low student mathematics learning outcomes are caused by several factors, one of which is the selection of learning models. The teacher has not applied learning with innovative models. So that mathematics learning is less varied and interesting.

Related to monotonous and unattractive learning problems that have an impact on low student learning outcomes, it is time to fix the process of learning mathematics especially regarding models, approaches, or techniques used in learning. Teachers need to choose an appropriate learning model to be applied in mathematics learning in elementary school early grades which can simultaneously solve problems in learning mathematics (Mastur, 2019; Putra, 2017). Some learning models that can be applied in learning mathematics in elementary school early grades include contextual teaching and learning models and problem-based learning models.

Contextual learning is learning that is holistic or holistic. This learning helps students to understand teaching material by relating it to everyday life. Thus, helping students have dynamic and flexible knowledge and skills. Contextual learning makes students actively build their own understanding (Ariestuti, Darsana, \& Kristiantari, 2014; Pinwanna, 2015).

Problem-based learning is learning that is based on a problem. The emphasis of learning is more directing students in solving a problem in learning using different strategies or ways of solving a problem in general. Thus, helping students have critical thinking skills and problem-solving skills (Birgili, 2015; Merritt, Lee, Rillero, \& Kinach, 2017).

Several previous studies have been conducted by Laili (2016), Simbolon \& Tapilouw (2015), Trisnawati, Sudargo, \& Prasetyowati (2019) regarding the contextual teaching and learning model and problem-based learning. However, from 
DOI: https://doi.org/10.24127/ajpm.v9i3.2779

some previous studies there has not been a comparative study between contextual learning models and problem-based learning that is applied to elementary mathematics learning in early grades. In this study, differences in learning outcomes between the two models are used as a basis in determining the appropriate learning model applied to mathematics learning in early grades of elementary school.

Based on the description above, the contextual learning model and problembased learning can be an alternative model that is applied in mathematics learning in the early grades. Therefore, this study aims to find out appropriate learning models to be applied in elementary mathematics learning in early grades in terms of student learning outcomes.

\section{RESEARCH METHODS}

This research is a quantitative study using quasi-experimental research methods. In this study, a treatment was given to determine the effect of the treatment on certain elements measured. The treatment given is in the form of applying contextual teaching and learning models and problem-based learning. While the aspect measured is the mathematics learning outcomes of third-grade students in elementary school.

The variables in this study consisted of two variables, namely independent variables and dependent variables. The independent variable in this study is the learning model that is applied in mathematics learning in elementary grades (contextual teaching and learning and problem-based learning) in the first experimental class and the second experimental class. The dependent variable in this research is the mathematics learning outcomes of third-grade students in elementary school.

This quasi-experimental research uses the posttest-only control design. So, the test is only done once, that is after learning takes place. Below is described the research design used by researchers.

Table 1. Experimental Research Design

\begin{tabular}{ccc}
\hline Class & Treatments & Posttest \\
\hline Control & $\mathrm{T}_{0}$ & $\mathrm{O}_{0}$ \\
$1^{\text {st }}$ Experimental & $\mathrm{T}_{1}$ & $\mathrm{O}_{1}$ \\
$2^{\text {nd }}$ Experimental & $\mathrm{T}_{2}$ & $\mathrm{O}_{2}$ \\
\hline
\end{tabular}

Explanation:

$\mathrm{P}_{0}$ : no treatments

$\mathrm{P}_{1}$ : applying CTL model

$\mathrm{P}_{2}$ : applying PBL model

$\mathrm{O}_{0}$ : control class posttest

$\mathrm{O}_{1}$ : first experimental class posttest

$\mathrm{O}_{3}$ : second experimental class posttest

The population of this study was 3rd grade of elementary school students in Wonosari Village, Semarang City, totaling 207 students and divided into six classes in three elementary schools. The research sample was determined randomly through cluster random sampling techniques. The sample in this study consisted of three classes, including two experimental classes and one control class. Students of class IIIA of SDN Wonosari 02 as a first experimental class, students of class IIIB of SDN Wonosari 02 as a second experimental class, and students of class III-B of SDN Wonosari 03 as control class. The number of students in each experimental and control class was 39 students. So, the total sample is 117 students.

Data collection was carried out through two techniques, namely 
DOI: https://doi.org/10.24127/ajpm.v9i3.2779

documentation and testing. To find out the initial conditions of students' mathematical abilities used documentation techniques by looking at student learning outcomes that have been documented by the teacher. Meanwhile, to obtain data on student mathematics learning outcomes used the second technique, namely the test. The form of the test used is five essay questions. The test is done after the test instruments meet the validity and reliability criteria through empirical tests that have been done before.

Data analysis in this study uses descriptive analysis techniques. Research data in the form of learning outcomes were analyzed using the oneway ANOVA test. One-way ANOVA test was used to test the difference in average student learning outcomes from three sample groups. However, before the one-way ANOVA test is carried out, two prerequisite tests must be performed. The two prerequisite tests are a normality test and homogeneity test. If both pre-test requirements are met, then a one-way ANOVA test can be performed. Data analysis results will interpret student mathematics learning outcomes between the first experimental class, second experimental class, and control class.

\section{RESULTS AND DISCUSSION}

The results obtained are quantitative data in the form of student mathematics learning outcomes through tests given at the end of learning. 117 students took the test, including 39 students from the first experimental class, 39 students from the second experimental class, and 39 students from the control class. Student learning outcomes are then compared to see differences in mathematics learning outcomes of the three groups. Descriptive analysis of mathematics learning outcomes of the three groups can be seen in Table 2 .

Table 2. Results of Descriptive Analysis of Student Learning Outcomes

\begin{tabular}{cccccc}
\hline \multirow{2}{*}{ Class } & \multirow{2}{*}{$\mathbf{X}_{\max }$} & $\mathbf{X}_{\min }$ & \multicolumn{3}{c}{ Central Tendency } \\
\cline { 4 - 6 } & & & $\overline{\boldsymbol{x}}$ & $\mathbf{s}^{\mathbf{2}}$ & $\mathbf{S}$ \\
\hline $1^{\text {st }}$ Experimental & 94 & 21 & 63.97 & 348.71 & 18.67 \\
$2^{\text {nd }}$ Experimental & 91 & 16 & 50.67 & 303.75 & 17.43 \\
Control & 77 & 14 & 40.23 & 191.13 & 13.82 \\
\hline
\end{tabular}

Posttest results at the end of learning from the three classes showed differences. In the class that applies the contextual teaching and learning model (the first experimental class), an average of 63.97 with the highest score is 94 and the lowest value is 21 . The class that applies the problem-based learning model (the second experimental class), has an average value of 50.67 with the highest value of 91 and the lowest value of 16. The control class applying conventional learning obtained an average of 40.23 with the highest value of 77 and the lowest value of 14. Based on these descriptive statistical data, the average student learning outcomes in the first experimental class who applied the contextual teaching and learning model were the highest compared to the 
DOI: https://doi.org/10.24127/ajpm.v9i3.2779

class that applied the problem-based learning model and the control class that applied conventional learning. It can be interpreted that the contextual teaching and learning model in general is more effectively applied in early grade learning in primary schools than the problem-based learning model and conventional learning.

After obtaining data on student mathematics learning outcomes, it is necessary to know the normality of data from the three classes. The first experimental class has a significance value of $p=0.066>\alpha=0.05$. The second experimental class has a significance value of $p=0.48>\alpha=$ 0.05 . The control class has a significance value of $p=0.614>\alpha=$ 0.05 . This shows that the significance value of each class is greater than $\alpha=$ 0.05 , so it can be concluded that the learning outcomes of the three classes have normal distribution data. Below, the results of the normality test data recapitulation of the first experimental class, second experimental, and control class are presented in Table 3.

Table 3. Normality Test of Learning Outcomes

\begin{tabular}{llcccccc}
\hline \multirow{2}{*}{ Class } & \multicolumn{3}{c}{ Kolmogorov-Smirnov $^{\boldsymbol{c}}$} & \multicolumn{3}{c}{ Shapiro-Wilk } \\
\cline { 3 - 8 } Learning & & Statistics & $\boldsymbol{d f}$ & Sig. & Statistics & $\boldsymbol{D f}$ & Sig. \\
\cline { 2 - 8 } Outcomes & $1^{\text {st }}$ Experimental & .191 & 39 & .001 & .947 & 39 & .066 \\
& $2^{\text {nd }}$ Experimental & .102 & 39 & .200 & .974 & 39 & .480 \\
& Control & .083 & 39 & .200 & .978 & 39 & .614 \\
\hline
\end{tabular}

a. Lilliefors Significance Correction, $\alpha=0,05$

After knowing the result of normal distribution data, the next test that needs to be done is homogeneity test. The data is declared homogeneous if the significance or $\mathrm{p}$-value $>\alpha(\alpha=$ 0.05). Homogeneity test results have a significance $=0.067$. Significance value of $p>\alpha(0.067>0.05)$. So, it can be concluded that the learning outcomes are homogeneous. The following results of the homogeneity test can be seen in table 4 .

Table 4. Homogeneity Test of Learning Outcomes.

\begin{tabular}{lccccc}
\hline \multirow{2}{*}{$\begin{array}{l}\text { Learning } \\
\text { Outcomes }\end{array}$} & $\begin{array}{c}\text { Levene } \\
\text { Statistic }\end{array}$ & $\boldsymbol{d f 1}$ & $\boldsymbol{d f 2}$ & Sig. \\
\cline { 2 - 5 } & 2.773 & 2 & 114 & .067 \\
\hline
\end{tabular}

Based on the normality test and homogeneity test, the learning outcome data fulfills the next test, which is the average difference test. The average difference test was performed with the one-way ANOVA test because the study had a sample of more than two groups. Student learning outcomes are stated to have significant differences in learning outcomes if the significance value $\mathrm{p}<\alpha=0.05$. The significance value of $p$ obtained was 0.002 , then $p<$ $\alpha$. The learning outcomes of the three classes can be concluded to have significant mean differences. This significant difference in the mean can be seen that there are effective and ineffective learning models to be applied in mathematics learning in the early grades of elementary school. In 
DOI: https://doi.org/10.24127/ajpm.v9i3.2779

this study, the contextual teaching and learning model is the most effective model compared to the problem-based learning model and conventional learning. The following are the results of the calculation of the average difference test of students' mathematics learning outcomes data using the oneway ANOVA test in Table 5.

Table 5. ANOVA Test of Learning Outcomes.

\begin{tabular}{ccccc}
\hline Class & Mean & $\boldsymbol{d} \boldsymbol{f}$ & $\boldsymbol{F}$ & Sig. \\
\hline $\mathrm{P}_{1}$ & 63.97 & 116 & 19.64 & .002 \\
$\mathrm{P}_{2}$ & 50.67 & & & \\
$\mathrm{P}_{0}$ & 40.23 & & & \\
\hline
\end{tabular}

The results of the study stated that the use of different models in learning mathematics in elementary school early grades, gave different student learning outcomes. This is in line with the posttest results showing that there are significant differences in average learning outcomes between the three classes. Mathematical learning outcomes of students who apply the contextual teaching and learning model are better than classes that apply the model of problem-based learning and conventional learning.

The learning process in the class that applies the contextual teaching and learning model looks more active. The enthusiasm of students in learning mathematics can be seen from the activeness of students when working on solving the problems given by the teacher in each group. Each member of the group plays an active role in solving problems related to daily life. The learning process that links learning material with real-life makes it easier for students to understand learning material. Besides, group learning activities also enhance communication skills and students' concern for mutual learning. This is in line with research conducted by Kusumadewi, Mariani, \& Susilo (2013), Ratih, Putra, \& Manuba (2014) which states that the application of the contextual teaching and learning model facilitates students in understanding learning material that is closely related to daily life so that it positively influences student learning outcomes.

The contextual teaching and learning model that emphasizes the association of teaching material with daily life is in line with the opinion of Abramovich, Grinshpan, \& Milligan (2019) which states that mathematics learning for early grades should be close to real life. Children have a high curiosity about the real world around them, so that curiosity can encourage students to learn and ultimately influence their understanding. Teachers should not limit mathematics and science learning for early grade students by using textbooks, but rather it is recommended to explore the surrounding environment to build student understanding (Clements \& Sarama, 2016).

The syntax or steps of contextual learning can emphasize student thinking activities in full, both physically and mentally. It is seen at the time of learning that students not only learn materially but the phases of the contextual teaching and learning model also make students learn physically and mentally. The seven phases which include constructivism, inquiry, asking, learning society, modeling, reflection, and assessment can develop all realms, both cognitive, psychomotor, and affective. This is in line with the opinion of Selvianiresa \& Prabawanto (2017) which states that the contextual learning process can make students 
DOI: https://doi.org/10.24127/ajpm.v9i3.2779

active by being involved during the learning process.

The concept of the environment as a source of learning in constructing concepts in learning is also following Piaget's theory of cognitive development (Maulana, 2017). In contextual learning students will actively try new things by connecting the experiences they have to construct the concept of knowledge independently. So, students become not passive because learning is not from sources and obtains meaningful learning in mathematics learning.

Unlike the contextual teaching and learning model, problem-based learning is less suitable for early elementary school students. Even though at this time the demands of learning are intensified, including the high order of thinking, but the reality on the ground is found several problems. Students tend to have difficulty in understanding the problems given. Besides, learning also requires a short amount of time in the application process. Both of these are problems experienced by teachers when applying the problem-based learning model.

This is in line with some research results of Adiga \& Adiga (2015), Eryilmaz (2011), and Supraptinah (2019) which mentions the weaknesses of the problem-based learning model, namely, if students have difficulty in solving problems will cause anxiety in learning mathematics, not a short time in applying the problem-based learning model, student motivation in learning is low because of lack of understanding the problems presented and requires a tutor for each study group to guide, so it requires a lot of human resources.

However, the application of the problem-based learning model in elementary schools has also been done before. Like research by Kaharuddin (2019) and Kartikasari \& Widjajanti (2017). Both studies were conducted with research subjects coming from high school elementary school students. So, it can be concluded that the problem-based learning model tends to be more appropriately applied to highgrade elementary school students who have a higher ability to think compared to early grade elementary school students.

Based on the discussion above, it can be concluded that the contextual teaching and learning model is more appropriate to be applied in early grade elementary schools than the problembased learning model. Early grades students who are in the concrete operational phase more easily understand learning by utilizing the surrounding environment in learning than solving problems that require more complex levels of thinking.

This study examines the application of an appropriate model in mathematics learning in elementary schools for early grade students in terms of average student mathematics learning outcomes. Research is limited to the cognitive domain to be assessed. So, there is a possibility to examine the application of contextual teaching and learning models and problem-based learning seen from the psychomotor and affective domains.

\section{CONCLUSION AND SUGGESTION}

Based on the analysis of the results of research and discussion, it can be concluded that there are differences in mathematics learning outcomes in the three classes of students who are praised. One of the differences is influenced by the learning model applied by the teacher. The appropriate learning model applied in elementary 
school mathematics learning in the early grades is the contextual teaching and learning model because it places more emphasis on meaningful learning from real life that makes it easy for students to understand learning. This is supported by the average student learning outcomes in mathematics applying contextual learning higher than student learning outcomes applying problem-based models and conventional learning. So, in learning the teacher must be able to choose the appropriate learning model to be applied in mathematics learning in elementary schools based on their grade level. Studies that are limited to the cognitive domain (student learning outcomes) in this study can be the basis for further research by reviewing the application of contextual learning models and problem-based learning from the psychomotor and affective domains to find out the effectiveness of the two learning models more deeply.

\section{REFERENCES}

Abramovich, S., Grinshpan, A. Z., \& Milligan, D. L. (2019). Teaching mathematics through concept motivation and action learning. Education Research International, 2019(1), 1-13. https://doi.org/10.1155/2019/3745 406

Adiga, U., \& Adiga, S. (2015). Problem based learning. International Journal of Current Research, 7(6), 17181-17187.

Ariestuti, P. D., Darsana, I. W., \& Kristiantari, R. (2014). Penerapan Pendekatan Contextual Teaching And Learning ( CTL ) Untuk Meningkatkan Keaktifan Dan Hasil Belajar IPA Siswa Kelas VI SDN 3 Tonja Tahun Ajaran
2014/2015. Jurnal Mimbar PGSD Universitas Pendidikan Ganesha, 2(1).

Astriyani, A. (2016). Peningkatan hasil belajar peserta didik dengan penerapan model pembelajaran problem solving berbantuan alat peraga. FIBONACCI: Jurnal Pendidikan Matematika Dan Matematika, 2(2), 1. https://doi.org/10.24853/fbc.2.2.17

Birgili, B. (2015). Creative and critical thinking skills in problem-based learning environments. Journal of Gifted Education and Creativity, 2(2), 71-71. https://doi.org/10.18200/jgedc.201 5214253

Clements, D. H., \& Sarama, J. (2016). Math, science, and technology in the early grades. Future of Children, 26(2), 75-94. https://doi.org/10.1353/foc.2016.0 013

Eryilmaz, A. (2011). Strenghts and weakness of probem-based learning in engineering education: students' and tutors' prespective. Buca Fakultesi Dergisi, 28(1), $40-58$.

Kahar, M. S., Anwar, Z., \& Murpri, D. K. (2020). Pengaruh model pembelajaran kooperatif tipe jigsaw terhadap peningkatan hasil belajar. AKSIOMA: Jurnal Program Studi Pendidikan Matematika, 9(2), 279-295.

Kaharuddin, A. (2019). Effect of problem based learning model on mathematical learning outcomes of 6th grade students of elementary school accredited B in 
DOI: https://doi.org/10.24127/ajpm.v9i3.2779

Kendari city. International Journal of Trends in Mathematics Education Research, 1(2), 43-46. https://doi.org/10.33122/ijtmer.v1i 2.14

Kartikasari, A., \& Widjajanti, D. B. (2017). Mathematical ConnectiThe Effectiveness of Problem-Based Learning Approach Based on Multiple Intelligences in Terms of Student's Achievement,on Ability, and SelfEsteem. Journal of Physics, 755(1).

Kusumadewi, O. N., Mariani, S., \& Susilo, B. E. (2013). Keefektifan CTL Berbantuan Macromedia Flash Terhadap Kemampuan Berpikir Kritis pada Materi Segiempat. Kreano: Jurnal Matematika Kreatif-Inovatif, 4(1), 57-63. https://doi.org/10.15294/kreano.v $4 \mathrm{i} 1.2887$

Laili, H. (2016). Keefektifan pembelajaran dengan pendekatan CTL dan PBL ditinjau dari motivasi dan prestasi belajar matematika siswa. PYTHAGORAS: Jurnal Pendidikan Matematika, 11(1), 25-34.

Mastur, Z. (2019). Kemampuan pemecahan masalah matematika menggunakan model pembelajaran kancing gemerincing berbasis budaya Jawa. Prosiding Seminar Nasional Matematika, 2, 171177. Retrieved from https://journal.unnes.ac.id/sju/inde x.php/prisma/issue/view/1445
Maulana, M. (2017). Konsep Dasar Matematika dan Pengembangan Kemampuan Berpikir KritisKreatif. Sumedang: UPI Sumedang Press.

Merritt, J., Lee, M. Y., Rillero, P., \& Kinach, B. M. (2017). Problembased learning in K-8 mathematics and science education: A literature review. Interdisciplinary Journal of Problem-Based Learning, 11(2). https://doi.org/10.7771/15415015.1674

Mu'min, A., Kamelia, \& Halmuniati. (2017). Meningkatkan hasil belajar matematika melalui model pembelajaran kooperatif tipe team assisted individualization (tai) pada siswa kelas $\mathrm{v}$ mi asysyaf'iyah kendari. Journal of Chemical Information and Modeling, 10(2), 55-72. https://doi.org/10.1017/CBO9781 107415324.004

Pinwanna, M. (2015). Using the Contextual Teaching and Learning Method in Mathematics to Enhance Learning Efficiency on Basic Statistics for High School Students. The International Conference On Language, Education, Humanities \& Innovation, 21(22), 58-63.

Putra, F. G. (2017). Eksperimentasi Pendekatan Kontekstual Berbantuan Hands On Activity (HoA) Terhadap Kemampuan Pemecahan Masalah Matematik. Al-Jabar: Jurnal Pendidikan Matematika, 8(1), 73. https://doi.org/10.24042/ajpm.v8i 1.1148 
DOI: https://doi.org/10.24127/ajpm.v9i3.2779

Ratih, N. K. A. N., \& Putra, I Ketut Adnyana Putra. Manuba, I. B. S. (2014). Pengaruh Pendekatan Contextual Teaching Andlearning (CTL) Melalui Pemodelan Mediasederhanaterhadap Hasil Belajarmatematikasiswa Kelas V SD Gugus III Kecamatan Gianyar. Journal Mimbar PGSD Universitas Pendidikan Ganesha, Vol. 2(1).

Riyanti, R., Sutama, S., \& Maryadi, M. (2017). Manajemen Pembelajaran Matematika di SD Negeri Mangkubumen 83 Surakarta. Jurnal VARIDIKA, 29(1), 65-74. https://doi.org/10.23917/varidika. v29i1.5150

Selvianiresa, D., \& Prabawanto, S. (2017). Contextual Teaching and Learning Approach of Mathematics in Primary Schools. Journal of Physics: Conference Series, 895(1). https://doi.org/10.1088/17426596/895/1/012171
Simbolon, E. R., \& Tapilouw, F. S. (2015). Pengaruh pembelaharan berbasis masalah dan pembelajaran kontekstual terhadap berpikir kritis siswa smp. EDUSAINS Journal, 7(1), 97104.

https://doi.org/10.1017/CBO9781 107415324.004

Supraptinah, U. (2019). Upaya meningkatkan kemampuan pemecahan masalah matematika siswa melalui penerapan model problem based learning. Jurnal Litbang Sukowati, 2(2), 48-60.

Trisnawati, Y. I., Sudargo, \& Prasetyowati, D. (2019). Efektivitas model contextual teaching and learning dan model problem based learning untuk meningkatkan kemampuan pemahaman konsep matematis siswa smp. Imajiner: Jurnal Matematika Dan Pendidikan Matematika, 1(5), 190-200. 